Tim Murphy, Chief

Bureau of Federal Facilities

Division of Environmental Protection

1771 E. Flamingo Road, Suite 121-A

Las Vegas, NV 89119

\title{
SUBMITTAL OF FINAL POST-CLOSURE INSPECTION LETTER REPORT FOR CORRECTIVE ACTION UNIT 112: AREA 23 HAZARDOUS WASTE TRENCHES, NEVADA TEST SITE, NEVADA, REVISION 0, JANUARY 2007
}

This letter serves as the post closure monitoring letter report for the above CAU for the period October 2005 - September 2006.

Quarterly inspections were conducted on December 12, 2005, on March 23, 2006, on June 20, 2006, and on September 19, 2006, to observe the condition of the gate, use-restriction warning signs, monuments, fencing, trenches, soil covers, and monitoring well covers.

The first inspection was conducted on December 12, 2005. Signs, fencing, riprap, monuments, and monitoring well covers were in excellent condition. No cracking, erosion, or subsidence was observed on the covers. No issues or concerns were identified, and no corrective actions were recommended.

The second inspection was conducted on March 23, 2006. Signs, fencing, riprap, monuments, and monitoring well covers were in excellent condition. No cracking, erosion, or subsidence was observed on the covers. No issues or concerns were identified, and no corrective actions were recommended.

The third inspection was conducted on June 20, 2006. Signs, fencing, riprap, monuments, and monitoring well covers were in excellent condition. No cracking, erosion, or subsidence was observed on the covers. No issues or concerns were identified, and no corrective actions were recommended.

The fourth inspection was conducted on September 19, 2006. Signs, fencing, riprap, monuments, and monitoring well covers were in excellent condition. No cracking, erosion, or subsidence was observed on the covers. No issues or concerns were identified, and no corrective actions were recommended. 
The post-closure inspection checklists for CAU 112 are attached. Photographs and field notes taken during site inspections are maintained in the project files.

Please direct comments and questions to Sabine Curtis, of my staff, at (702) 295-0542.

ERP:

Wilhelm R. Wilborn, Acting Federal Project Director

Environmental Restoration Project

Enclosure:

As stated

cc w/encl. (uncontrolled):

D. R. Elle, NDEP, Las Vegas, NV

Southern Nevada Public Reading Room

Las Vegas, NV (2 electronic copies)

Northern Nevada Public Reading Room

Carson City, NV (electronic copy)

Public Reading Facility Coordinator, SNJV

Las Vegas, NV (electronic copy)

David Swanson, Department of Natural

Resources \& Federal Facilities, Pahrump, NV

Technical Library, NNSA NSO, Las Vegas, NV (clectronic copy)

NSTec Document Production (electronic copy to OSTI)

J. L. Smith, NSTec, Las Vegas, NV

R. F. Boehlecke, SNJV, Las Vegas, NV

EM Records, AMEM, Las Vegas, NV

S. T. Curtis, ERP, NNSA/NSO, Las Vegas, NV

R. J. Poderis, NSTec, Las Vegas, NV

G. Richardson, NSTec, Las Vegas, NV

A. J. Silvas, NSTec, Las Vegas, NV

T. A. Thiele, NSTec, Las Vegas, NV

cc w/o encl:

D. C. Loewer, DTRA/CXT1, M/S 645, Mercury, NV 
Tim Murphy, Chief

T. A. Lantow, DTRA/CXT1, M/S 645, Mercury, NV W. R. Griffin, SNJV/DTRA, M/S 645, Mercury, NV

K. A. Hoar, AD/AMSP, NNSA/NSO, Las Vegas, NV E. F. Di Sanza, WMP, NNSA/NSO, Las Vegas, NV

FFACO Group, PSG, NNSA/NSO, Las Vegas, NV 


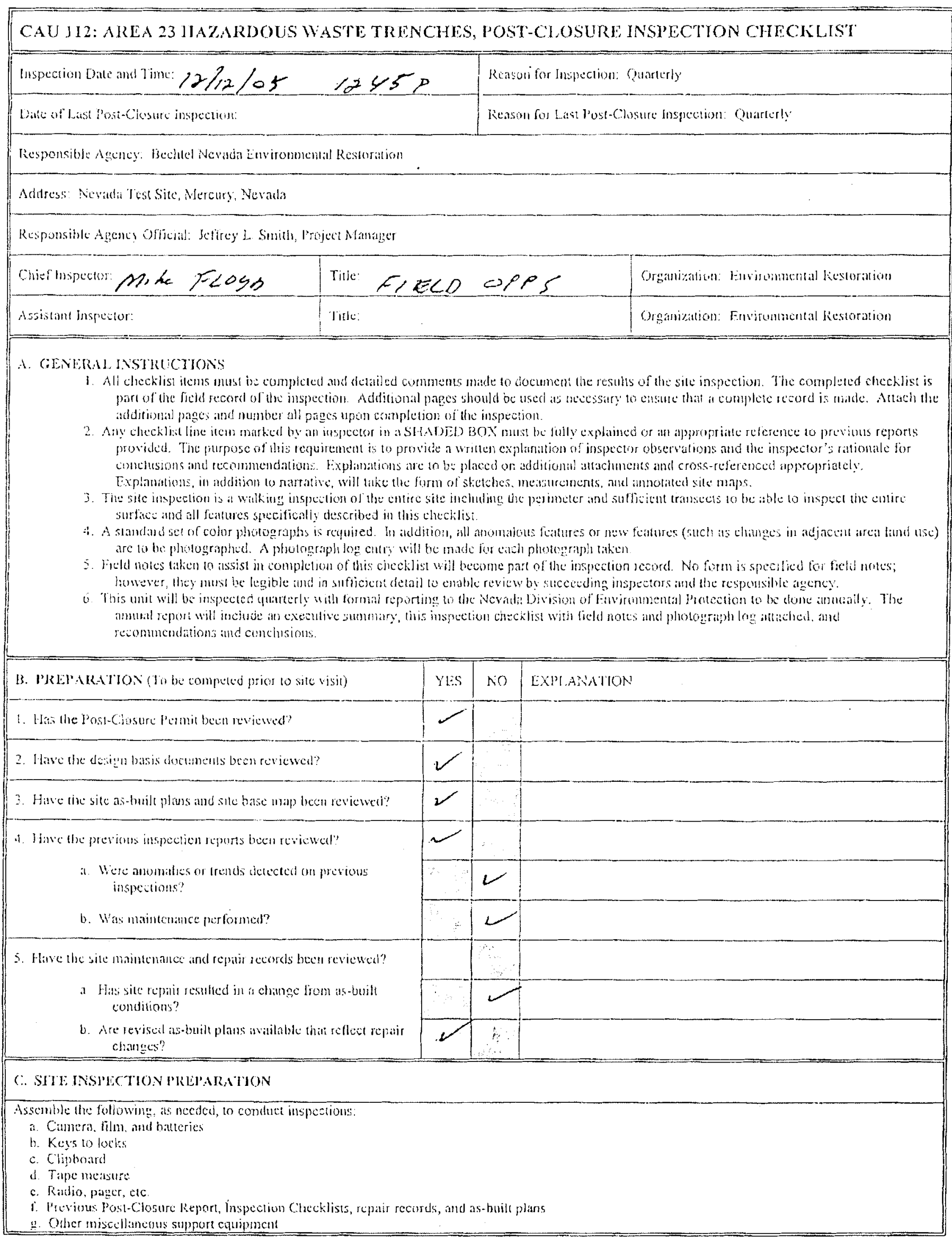


CAU 112: AREA 23 HAZARDOUS WASTE TRENCHES, POST-CLOSURE INSPECTION CHECKLIST

\begin{tabular}{|l|l|l|l|l|}
\hline D. SITLINSPICTION & YES & NO & EXPLMNATON \\
\hline
\end{tabular}

1. Adjaten oll-silt feiltures:

a. Have bite been iny chatheses in the use of the adjacen arta?

b Are there any new roads or walls:

c. Has there becen any change in the position of neaby washics?

d. Has there been titeral exencsion or erosimidepositim of uciuby wastics?

e. Are diere new drainge channdis?

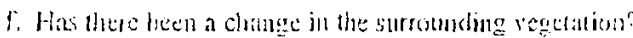

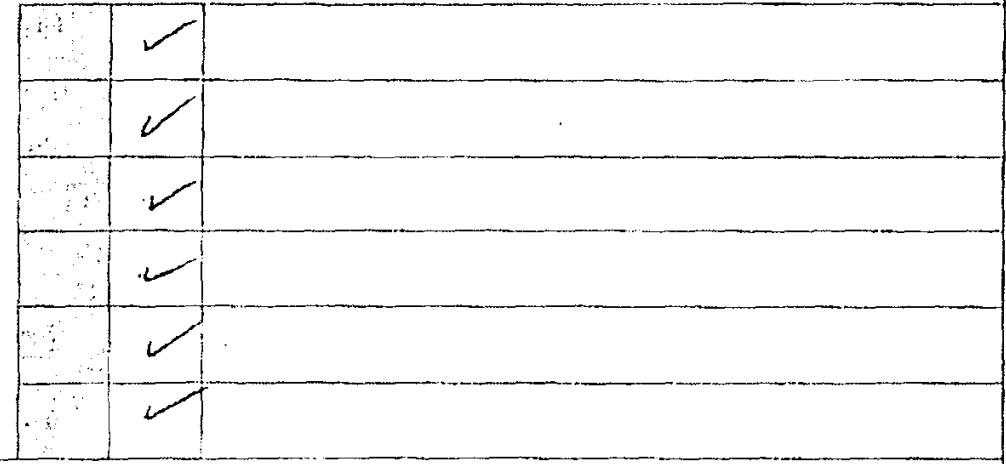

2. Acecso rouds, lences, sinter, and singes

it. Is there it break in the fence?

b. Have any nosk heen dimaged or their themoring weationed?

c. Does the gate show cridence of tallpering or damage?

d. Wis the gute locked?

e. Is hase any evidence of humb!n intrusien one dhe cover"

f. Is there any cridence of tarec onimal intrusun onte the cover"

1. Have any signt been dimaged of removect? (ivimber of signs repliaced:__

1. Oher"

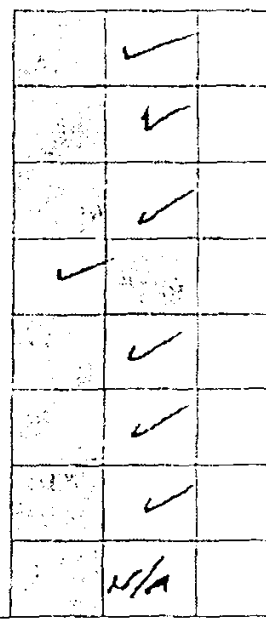

3. Wointments and olver permatnent features.

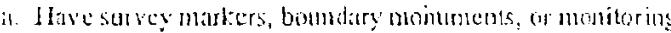
stations becoll disturbed?

b. Bo natual processes threaton the integrity of any strvey maker, boundary momument of montoring shation?

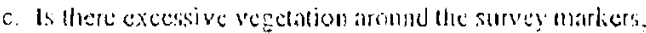
boundary monuments, or monitoring stations:?

d. Ouber"

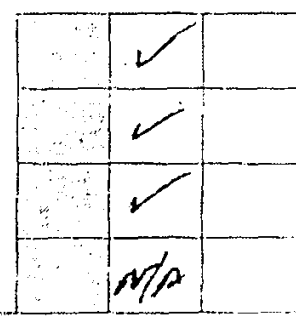

$\$$ Warte tmit cover:

a. Ls there evidence of scitling?

b. Is there evidence of ericking?

c. Is there evidence of trosion fwind or watery?

1. Ls there crisknce of animul burowing?

¿. Is there vegeration growing an the coner?

9. Ohuer (inchuding trash, dehris, ete wilhin fenced ateil)"

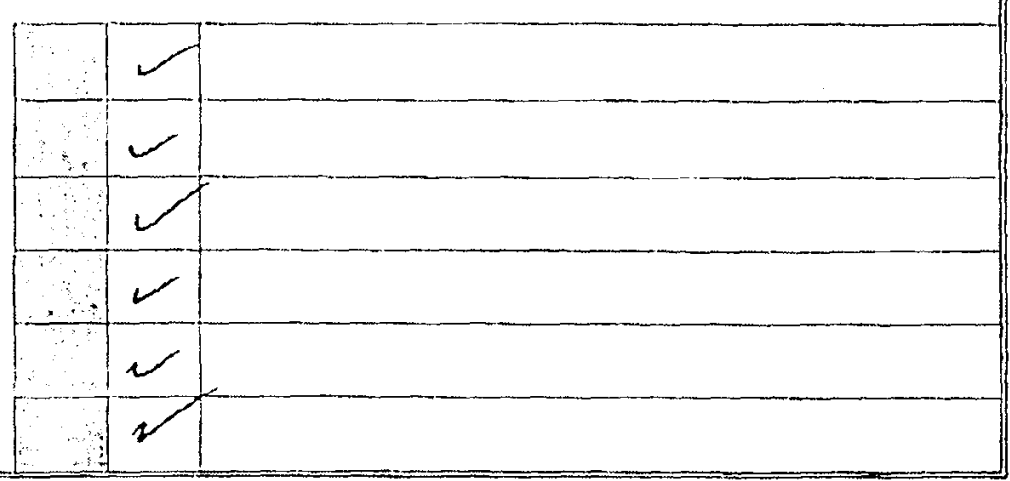


Page 3 of 3

CAU 112: AREA 23 HAZARDOUS WASTE TRENCHES, POST-CLOSURE INSPECTION CHECKLIST

E. FIELD CONCIUSIONS

1. Is there an immanem hazard to ble integrit: of the unit? (immediate repont segured)

Ferson Agoney to whom teport wits mitle:

2. Are mort frequem insperions requited?

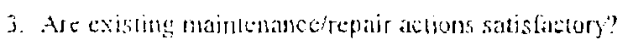

4 Is Gher maincuancedopatr necessary?

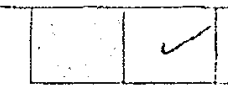

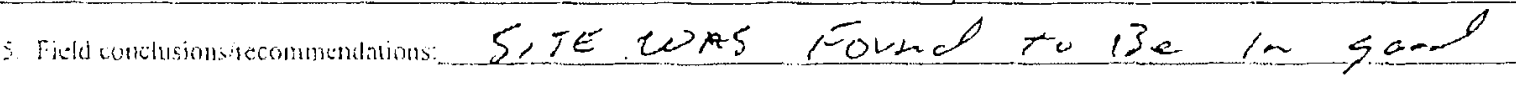

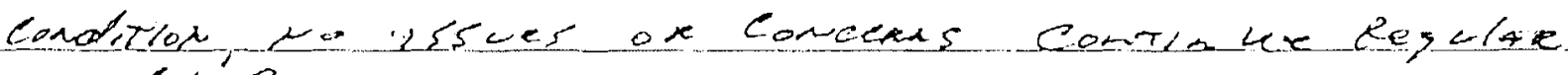

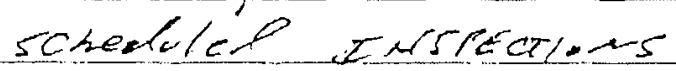

F. (1:RTHICATION

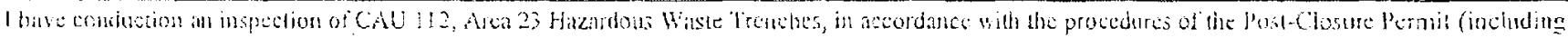

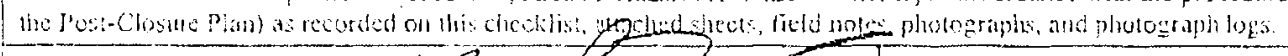

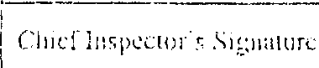

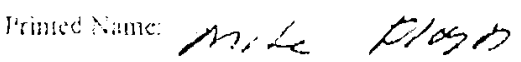

$21,2 x+5$

$12 / 12<0 \times$ 
Page 1 or 3

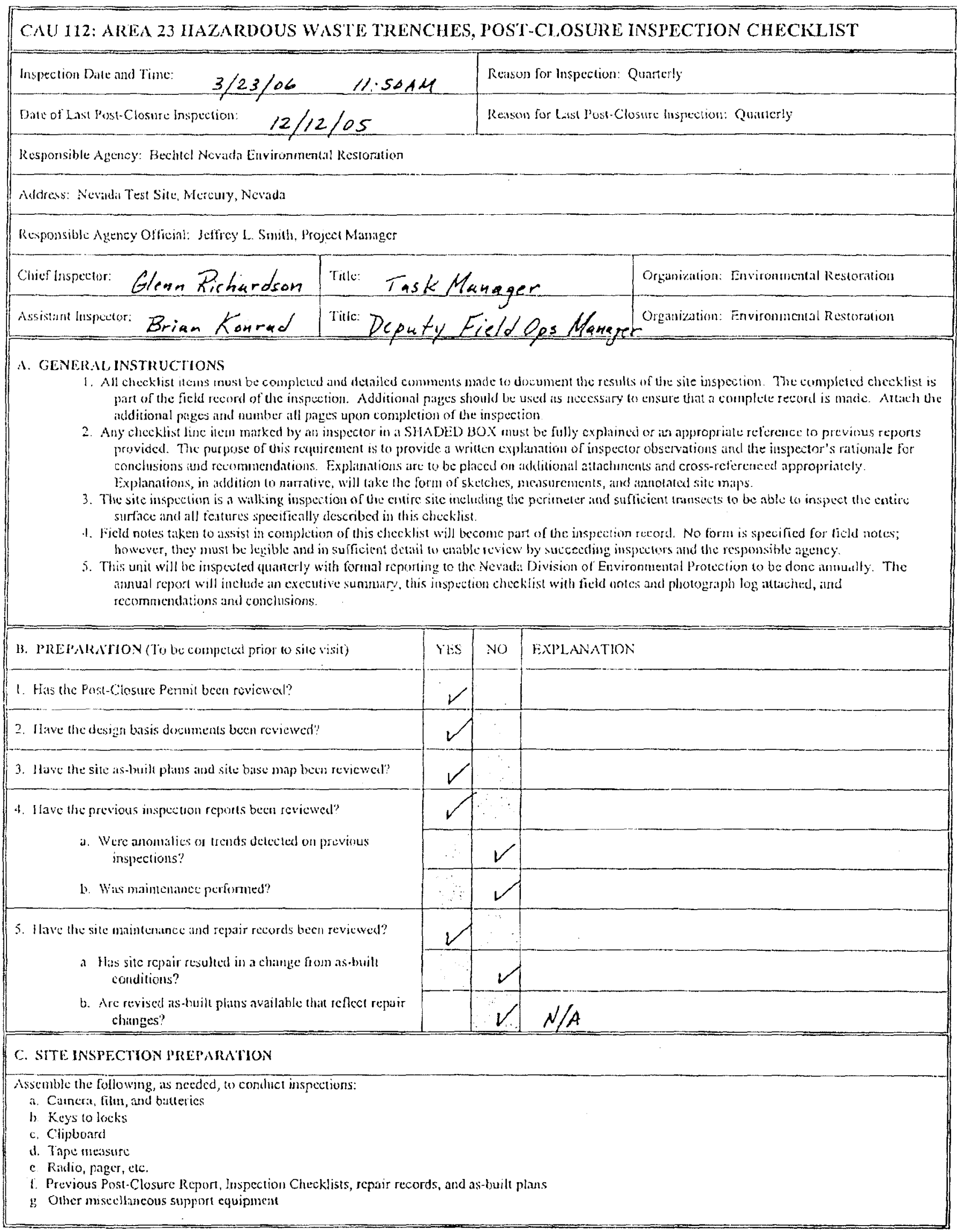


$\operatorname{Page} 2$ of 3

CAU 112: AREA 23 IIAZARDOUS WASTE TRENCHES, POST-CIOSURL INSPECTION CIIECKLIST

\begin{tabular}{|l|l|l|l|l|l|l|}
\hline D. STTEINSPECTION & YIES & NO & EXPLANATION \\
\hline
\end{tabular}

1. Ailjacenl off sitc leitures.

a. Have there beco any changes in die use of the andjicent asen?

b. Are there any new roads or trails?

c. Has there beer any chunge in die position or ncarby washes"?

4. Has there been bateral excursion or erosiondeposilion of nearby washes"?

c. Are these new drainape dannels?

¿. Has licere been a change in the surrounding vegetation?

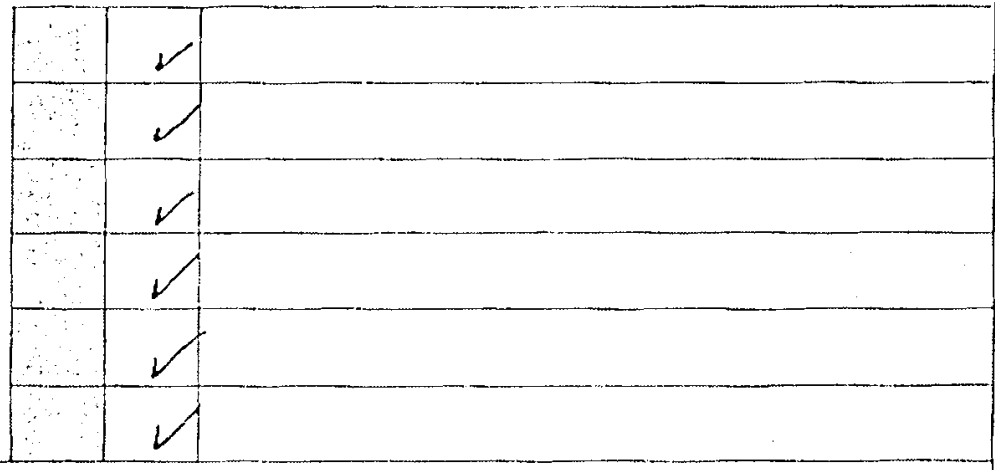

2. Access rondi, fences, gales, and signs:

a. Is there a hreit: in the fence?

b. Have iny prosts been thinaged or their anchoring woikened?

c. Dows dhe gate slisw evidence of lamparing or damage?

d. Bus the gite locked"

c. Is there any avidente of buman intusion onto the cover?

f. Is there any evidence of farge animal imrasion onto the cover?

6. Halbe iny signtis ben damaged on removed?

(Number of signs replacel: 8 )

1.. Oriver?

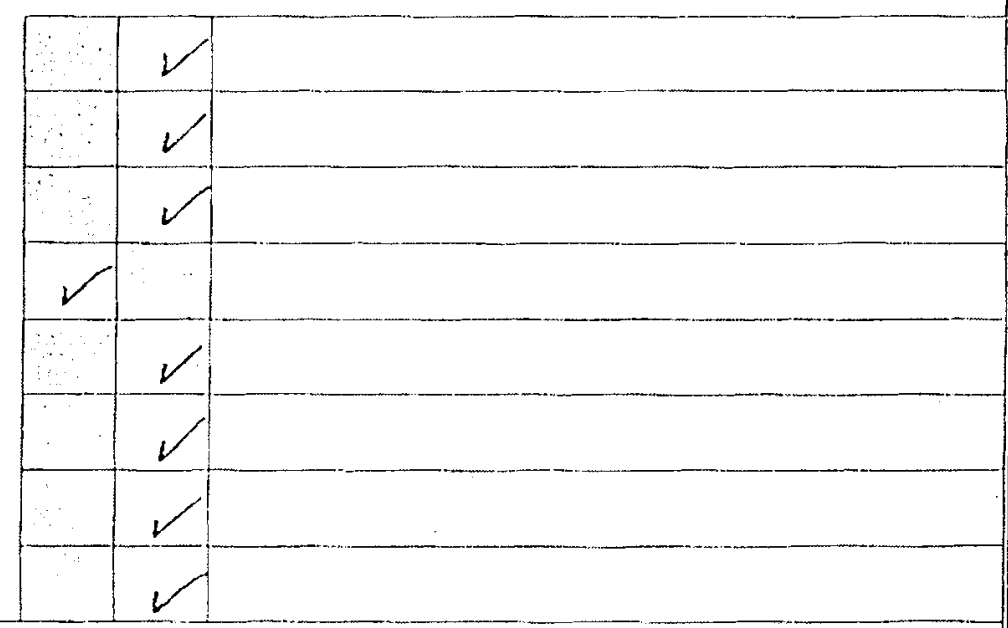

3. Monumemts and ither permument features

it. Hawe survey markess, boundary monements, or monites inge stations been disturbed?

b. Do natural proceises dareaten the integrity of any survey marker. Mxundary momunen or monitoring station"?

c th there excessive vegetation arotind the survey martess, boundary monuments, or moujtoring stations?

d. Othrs?

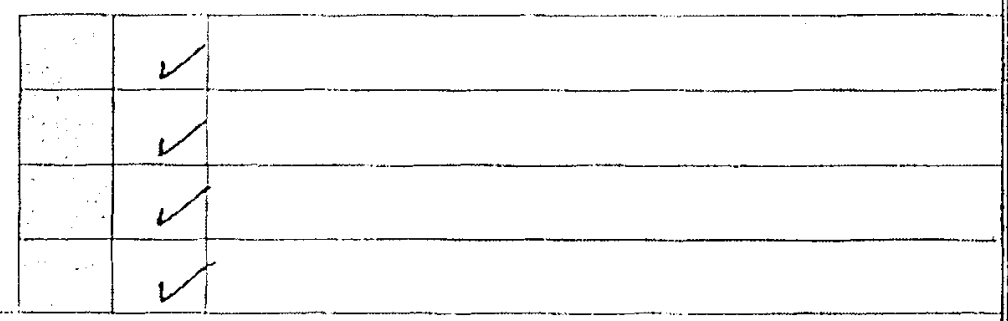

4. Waste unit cover:

a. Is there cridence or setting?

b. Is there cuidence of erracking?

c. Lis there evidence of eroxion (wind or waller)?

d. Is there cridence of animal burrowing?

c. Is there vegutation growing on the cover?

g. Other (including trash, debris, ele within fenecd asea)?

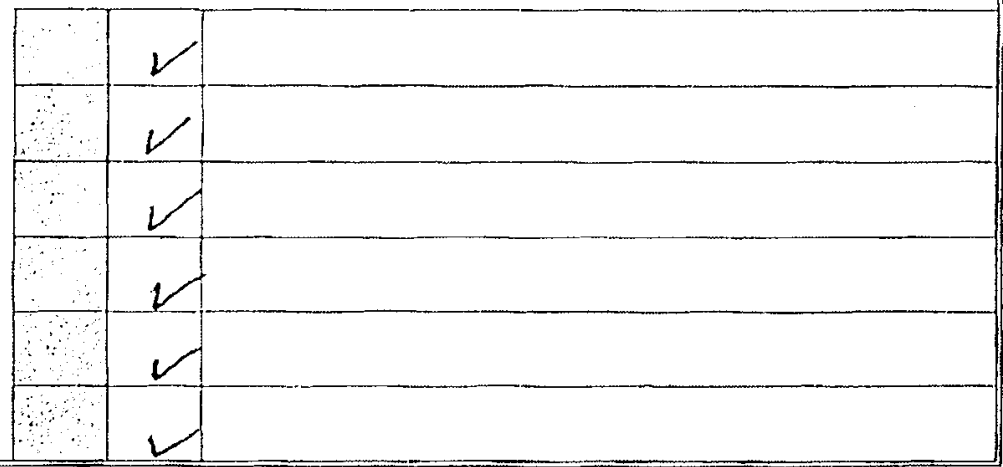


Page 3 of 3

CAU 112: AREA 23 HAZARDOUS WASTE TRENCHES, POST-CLOSURE INSPECTION CHECKLIST

F. HELD CONCLUSIONS

1. Is there an imminence bate ard to the integrity of the unit?

(linulediate report required)

Person h ency 10 whom report was made:

2. Are mare frequent inspections required?

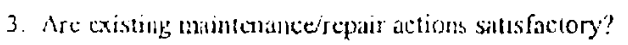

4. Is of her maimenancercipar necessity?

5. Fichliconcluximsírocommenditions:

There was no evidence of vegetation on the cover. The signs and fencing were in good condition.

F. CERTIFICATION

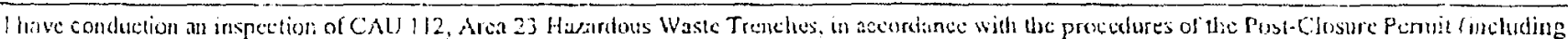
the Post-Closure Plan) an recorded on this checklist, attached sheets, and field notes.

Chic Inspector's Signature:

$3 / 23 / 06$

l'nuted Nama:

Glen Richardson

Task Manager 
Pinge 1 of 3

\begin{tabular}{|c|c|c|c|c|c|}
\hline \multicolumn{6}{|c|}{ CAU 112: AREA 23 HAZARDOUS WASTE TIRENCIIES, POST-CLOSURE INSPECTIONCHECKIAST } \\
\hline \multicolumn{3}{|c|}{ Inipection Dalc and Time: $6 / 20 / 06,11: 05$} & \multicolumn{3}{|c|}{ Ritanon for Insprection: Quarterly } \\
\hline \multicolumn{3}{|l|}{ Date of Lasa Poit-Closure Inspetion: } & \multicolumn{3}{|c|}{ Reason for Latst Post-Closure lnspection: Quarterly } \\
\hline \multicolumn{6}{|c|}{ Kesponsible Agency: Bechtel Revala Environmental Restoration } \\
\hline \multicolumn{6}{|l|}{ Addrecs: Fevada Yest Situ, Nercury, Gevada } \\
\hline \multicolumn{6}{|c|}{ Responsible Agency official: Jeffrey L. Smith, Project Manher } \\
\hline Chiefluspertar: Shamgin Burnison & \multicolumn{3}{|c|}{ Till: TECH LEAD } & & Orgumbation: Lavitonmental Resteration \\
\hline 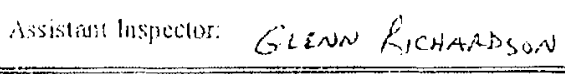 & \multicolumn{3}{|c|}{ Iiile: TASK MGR } & & Mganzation: Bovirommeitial Restoration \\
\hline \multicolumn{6}{|c|}{ 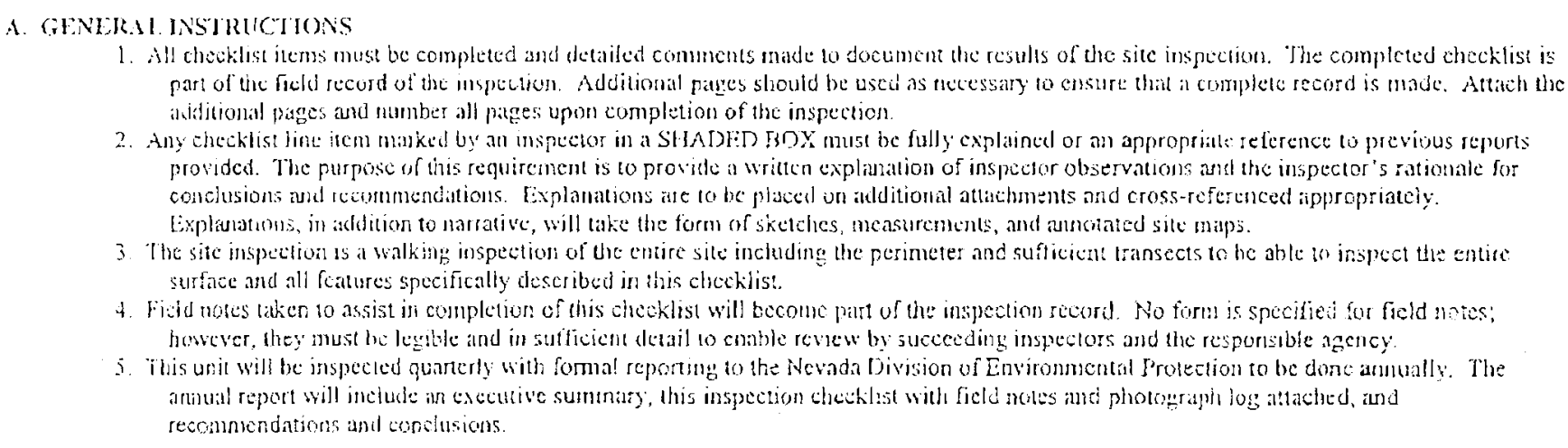 } \\
\hline \multicolumn{2}{|l|}{ B. PREPARSTION (To be competed prior to site visit) } & Yis & \multicolumn{3}{|c|}{ NO EXPIAIATION } \\
\hline \multicolumn{2}{|l|}{ 1. Has the I'ust-Closure Permit been reviewed? } & $x$ & & & \\
\hline \multicolumn{2}{|l|}{ 2. Hove the design basis documents lect retiewed"? } & K & & & \\
\hline \multicolumn{2}{|c|}{ 3. Hase the sice at-built plans ant ste basc map been reviewed? } & $x$ & 8 & & \\
\hline \multirow{3}{*}{\multicolumn{2}{|c|}{ 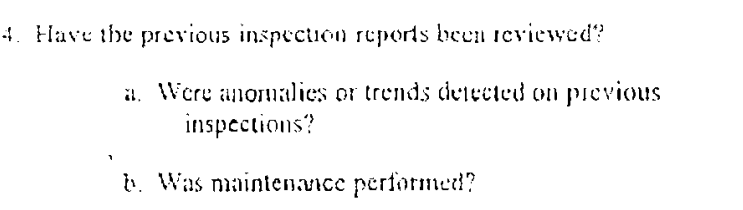 }} & $\lambda$ & 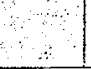 & & \\
\hline & & 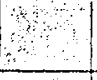 & $x$ & & \\
\hline & & & $x$ & & \\
\hline \multicolumn{2}{|c|}{ 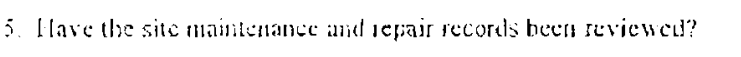 } & $x$ & 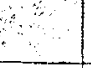 & & \\
\hline \multirow{2}{*}{\multicolumn{2}{|c|}{ 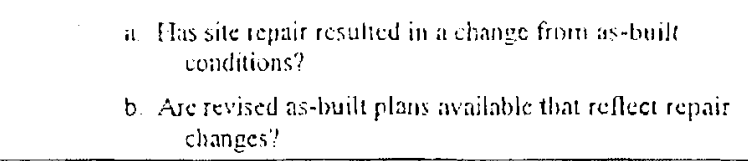 }} & & $x$ & & \\
\hline & & & to & $N / A$ & \\
\hline \multicolumn{6}{|l|}{ C. STIE INSPECTION PREPARUITON } \\
\hline \multicolumn{6}{|c|}{ 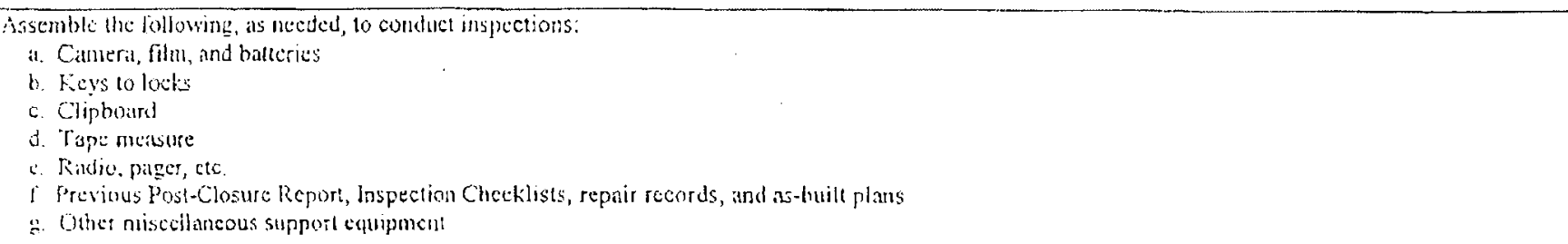 } \\
\hline
\end{tabular}


Time: 11:05

Page 2 of 3

CAU 112: AREA 23 HAZARDOUS WASTE TRENCHFS, POST-CLOSURE INSPECTION CIYCKLIST

D. STEEINSIECTIOY

\begin{tabular}{l|l|l} 
YES & NO & EXPLANATION:
\end{tabular}

1. Adjactont olf-slle fentures:

a Have there been any changes in the use of the adjacent all cis?

1. Are biere any new rouls or traits?

c. Has there been any change in the position of neirty washes?

1. Hat there been lateral exeursion or crosion/deposition of nourby washes?

c. Ave there new draillage channels?

f. Has there been at thange in the surtounding vegetation?

\begin{tabular}{|c|c|}
\hline 40 & $x$ \\
\hline ob & $x$ \\
\hline & $x$ \\
\hline क्ष & $x$ \\
\hline & $x$ \\
\hline & $x$ \\
\hline
\end{tabular}

2. Accoss ruids, ferecs, sates, ind signs:

a. Is there a break in the fence?

b. Have any posts bous damaged or their anchoring weakicued?

c. Dees the gate show eridence of tampering or taminge?

d. Was the gate locked?

c. Ts there any evidence of manan insusion onto the cover?

f Is there any evidence of lage antmat unsusion onte the cov'r?

g. Jlate any signs becin damiged or temovedl? Nunber of signs repliced:

h. Oliner?

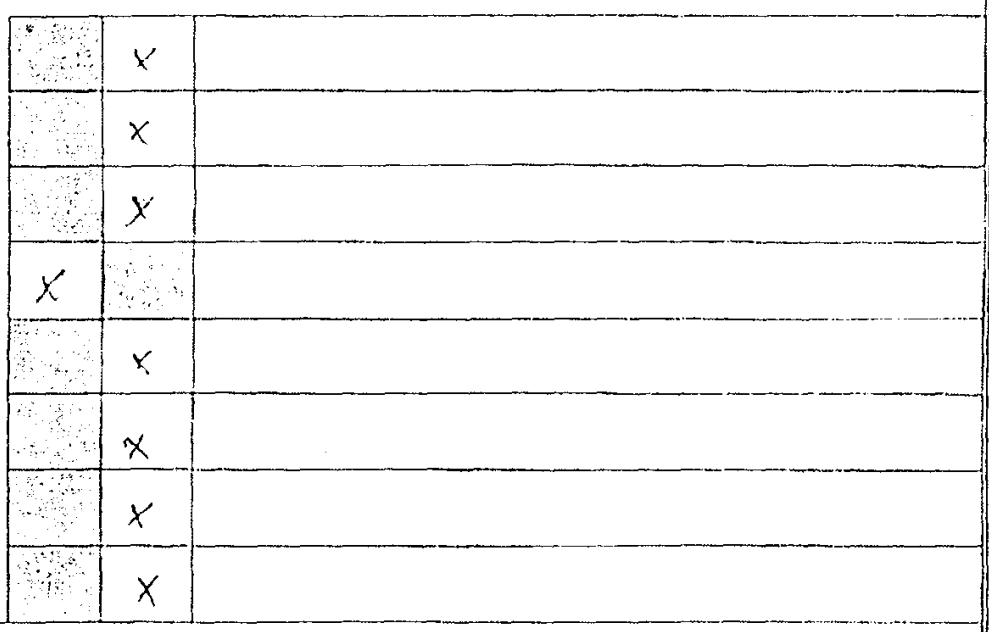

3. Nonuments and ober permanent featucs

a, Hawe survey maskers, boundary monumerits, or monitoring stitions been disturbed?

b. Do miblural pocesses thicalon the integrily of any survey master, boundary monument or monitoning station?

¿. Is here excessive vegetistion around the survey minkers, boundery menuments, or montiturin's stitions?

cl. Oher

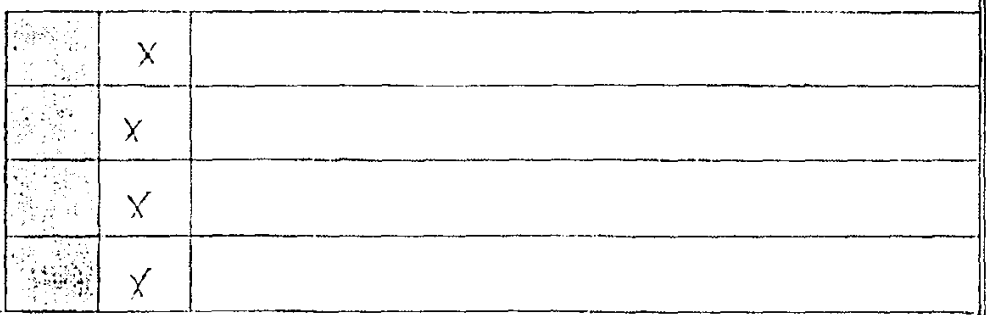

4. Waste unit cover:
a. Is there evidence of sctiling?
b. Is there eridence of cracking?
c. Is there evidence of erosion (wind or wattr)?
1. Is there evidence of animal burrowing?
e Is there vegetation growing on the cuver?
E. Other (ineluding erash, debris, alc within fenced nsen)?

\begin{tabular}{|c|c|c|}
\hline & $x^{\prime}$ & \\
\hline , & $X$ & \\
\hline bl & $x$ & \\
\hline $\begin{array}{r}9+30 \\
1+14\end{array}$ & $x$ & \\
\hline + & $x$ & 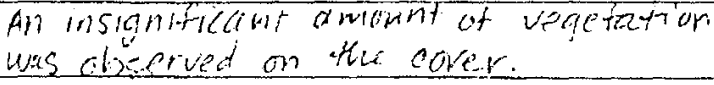 \\
\hline 4 & $x$ & \\
\hline
\end{tabular}




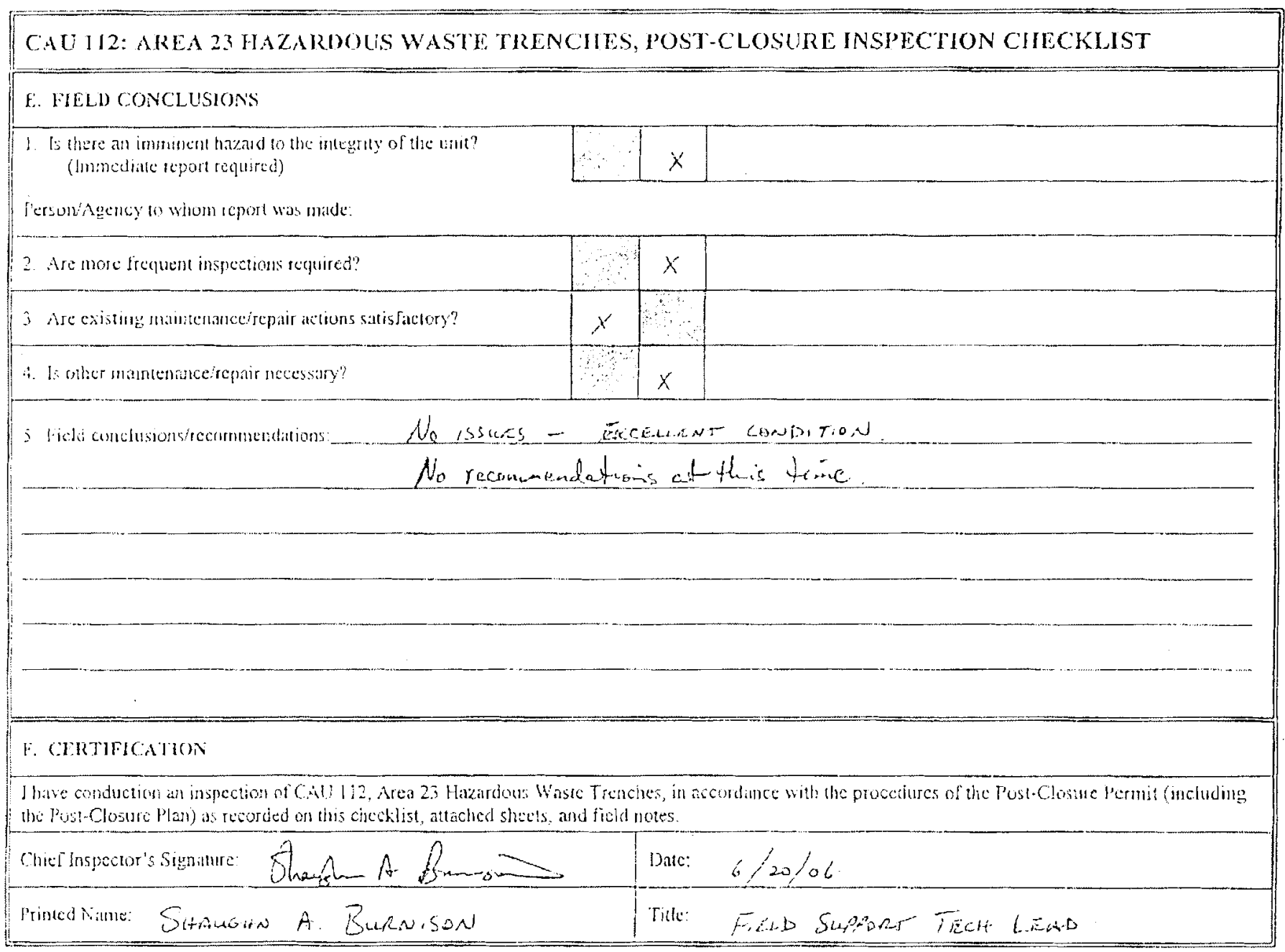




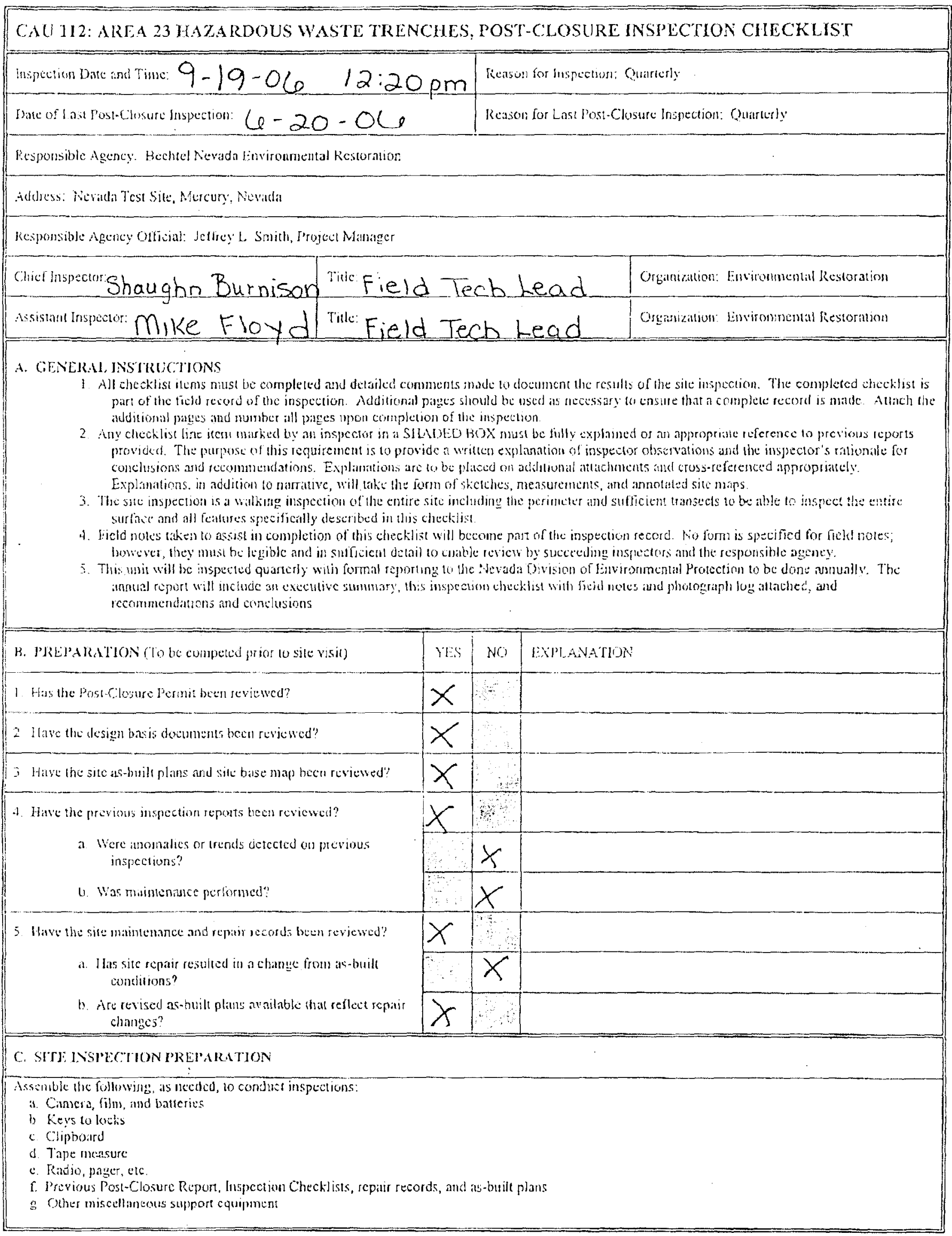




\section{CAU 112: AREA 23 YAZARDOUS WASTE TRENCHFS, POST-CLOSURE INSPECTHON CHECKLIST}

\section{1). SITEINSPECIIN}

1. Adiacent oif-site foatures

a. Have duere been ary changes in the use of the adjaeent areat?

b. Are there any new rosids of tritils?

c. Hids these been any change in the position of nearby washer?

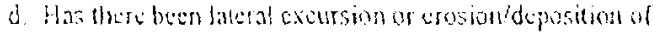
me'ilby washes?

c. Art there inew draimg chandels?

f. Hai there been a dange in die surrumbing vegetation?

2. Acersionds knces, gates, and sigus

4. Js there a break in the fence?

t. Have any pests been eamsed or their anchoring weakenteri"

c. Dows the sinte show evidence of thrnetring or diunage?

d. Was die wate lochent?

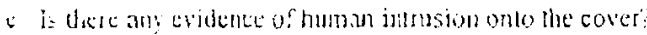

f. is there any evidene of large animal intrusion onto the cortert?

9. Have any signs bech damiged or moved? qumber of signs renbuced 0 .

h. once:"

3. Wonementis and other peraniand fenturts

a. Heve sursey norlicers, boundary monunents, o: monitorin stacions been distubbed?

b. Do natural processes the alen the integrity of any survey

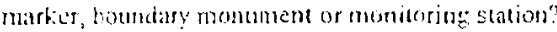

$\therefore$ Is there excessive vegetation alroud ale survey makers biondary mernencuts, of montoring stations?

1. Gher

Wase inli cover

a. Is there evidence of setthing?

b. St there evidence of cratinge?

i. Is dhere cusdence of erosion (wirnt or willer)"

d. Is there cyidence of animal burrowing?

2. Is there vegetation growing on the coves?

g. Other (including trash, debris, ok within fenced artal)?
YES NO EXILANATION

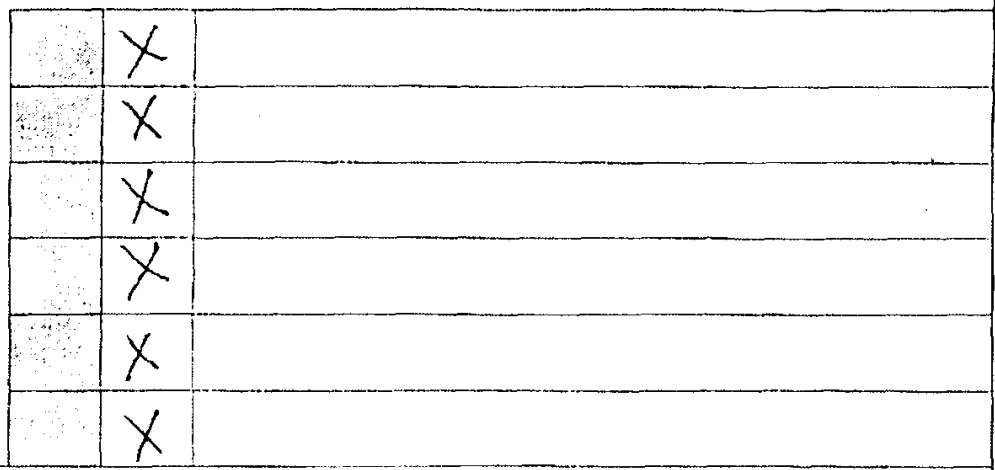

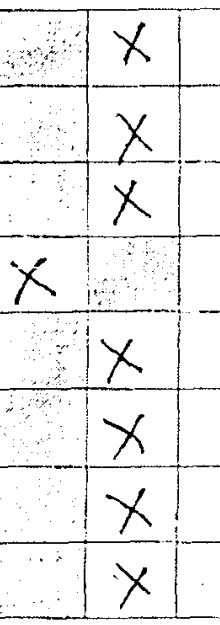

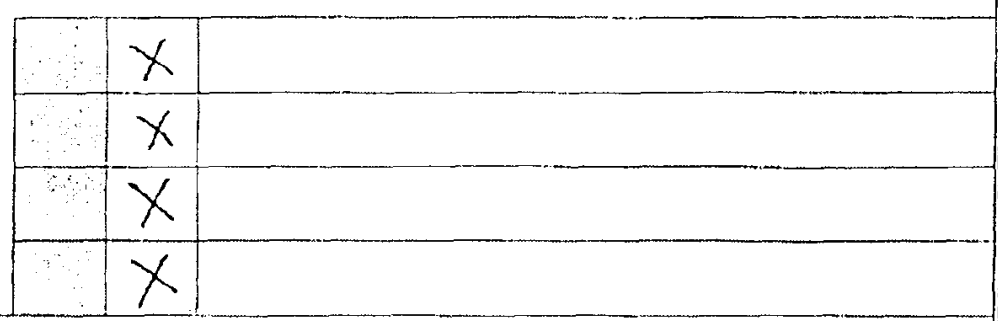


Page 3 of 3

CALI 112: AREA 23 HAZARDOUS WASTE TRENCHES, MOST-CLOSURE INSPECTION CHECKLIST

R. FELT CONCLUSIONS

Is there an intament hazard to the integrity of the unit?

(Immediate report regluirted)

\begin{tabular}{r|r|}
\hline$x$ & $X$ \\
\hline
\end{tabular}

Ferion'Agency to whom report was made:

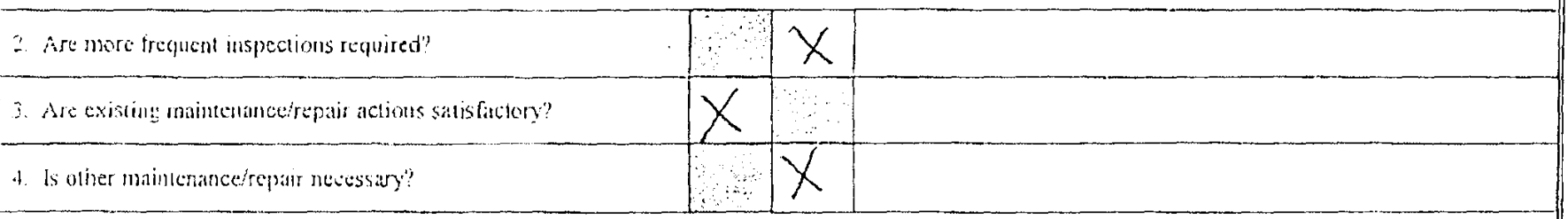

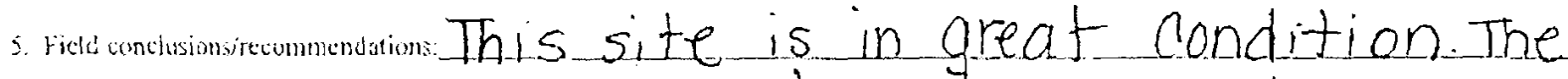
monuments were upright and no cracks were seen. The fence, sighs, and cover need no repairs. and no issues were identified.

F. CERMFICATION

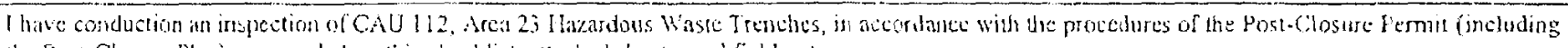
the Prosi-Closure Platy) as recorded an this checklist, attached sheets, and field aches

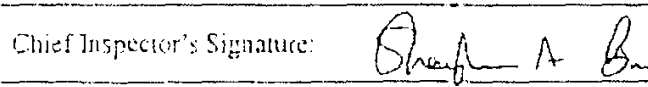

Date: $9 / 19 / 2006$

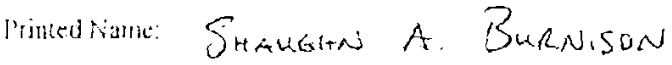

Title Field SuppoRt TECH LE AB 